\title{
The Relationship Between Cytomegalovirus Antibody (Anti-CMV) Test Positivity and Some Hematological and Biochemical Parameters in the Pediatric Age Group
}

\author{
Pediatrik Yaş Grubunda Cytomegalovirus Antikor (Anti-CMV) Testi \\ Pozitifliğinin Bazı Hematolojik ve Biyokimyasal Parametrelerle İlişkisi
}

\author{
Fethi BARLIK ${ }^{1}$, Mehmet PARLAK², Nesrin CEYLAN³, Yasemin BAYRAM², Huseyin GUDUCUOGLU²
}

\Van Yuzuncu Yil University, Van Vocational School of Health Services, Van, Türkiye

${ }^{2}$ Van Yuzuncu Yil University Faculty of Medicine, Department of Medical Microbiology, Van, Türkiye

3University of Health Sciences, Dr. Sami Ulus Obstetrics and Pediatrics Education and Research Hospital, Ankara, Türkiye

\begin{abstract}
Objective: Cases of Cytomegalovirus (CMV) infection are encountered in the early stages of life in developing countries. The aim of this study is to specify the seroprevalence of CMV-IgM and IgG in pediatric patients and to indicate its relationship with certain hematological, serological, and biochemical parameters.

Material and Methods: Serological test results of CMV-IgM and CMV-IgG in children aged 0-14 with CMV as a causative agent were analyzed retrospectively in the blood samples sent to the Microbiology Laboratory of Dursun Odabas Medical Center of Van Yuzuncu Yil University between 2013 and 2015. The relationship with hematological and biochemical parameters was investigated in the cases with positive CMV-IgM results.

Results: CMV-IgM and IgG tests were studied in 1.385 children. It was determined that $58 \%$ of these children were boys and $42 \%$ were girls. A total of $112(8.2 \%)$ of the 1.363 patients who were tested for CMV-lgM were found to be positive. The decrease in IgM with age was found to be statistically significant $(p<0.01)$. It was determined that 707 (95.3\%) of 742 patients who were tested for CMV-lgG were positive. Similarly, the increase in IgG parallel to age was found to be statistically significant $(\mathrm{p}<0.05)$. The correlation between positivity values of CMV-IgM-positive patients and patients' hematological, serological, and biochemical parameters were calculated separately. It was noted that the significant value in the correlation was C-reactive protein with $0.49(p<0.01)$.
\end{abstract}

Conclusion: CMV-lgG seroprevalence was found to be higher compared with studies conducted in developed countries. Accordingly, we think that increased C-reactive protein levels will be useful in the diagnosis of CMV.

Key Words: C-reactive protein, Cytomegalovirus, Hematologic parameters, Pediatrics

Öz

Amaç: Gelişmekte olan ülkelerde yaşamın erken dönemlerinde Cytomegalovirus (CMV) enfeksiyonu vakalarına rastlanmaktadır. Bu çalışmanın amacı, pediatrik hastalarda Sitomegalovirüs-lgM ve lgG seroprevalansını belirlemek ve bazı hematolojik, serolojik ve biyokimyasal parametrelerle ilişkisini araştırmaktır.

(1)
:0000-0003-2012-7255 :0000-0001-6030-2244 $: 0000-0001-5844-1261$ $: 0000-0001-6083-5550$ :0000-0003-1048-8268
Conflict of Interest / Çıkar Çatışması: On behalf of all authors, the corresponding author states that there is no conflict of interest. Ethics Committee Approval / Etik Kurul Onayr: This study was conducted in accordance with the Helsinki Declaration Principles. Van Yuzuncu Yil University Faculty of Medicine, Non-Invasive Clinical Research Ethics Committee (date: 10.03.2015, number: 08).

Contribution of the Authors / Yazarların katkıSI: BARLIK F: Taking responsibility in necessary literature review for the study, Taking responsibility in the writing of the whole or important parts of the study. PARLAK $\boldsymbol{M}$ : Constructing the hypothesis or idea of research and/or article, Planning methodology to reach the Conclusions, Organizing, supervising the course of progress and taking the responsibility of the research/ study. CEYLAN N: Organizing, supervising the course of progress and taking the responsibility of the research/study, Taking responsibility in logical interpretation and conclusion of the results, Taking responsibility in the writing of the whole or important parts of the study $\boldsymbol{B A Y R A M} Y$ : Taking responsibility in patient follow-up, collection of relevant biological materials, data management and reporting, execution of the experiments, Taking responsibility in logical interpretation and conclusion of the results, Reviewing the article before submission scientifically besides spelling and grammar. GUDUCUOGLU H: Taking responsibility in patient follow-up, collection of relevant biological materials, data management and reporting, execution of the experiments, Reviewing the article before submission scientifically besides spelling and grammar.

How to cite / Atıf yazım şekli : Barlik F, Parlak M, Ceylan N, Bayram Y and Guducuoglu H. The Relationship Between Cytomegalovirus Antibody (Anti-CMV) Test Positivity and Some Hematological and Biochemical Parameters in the Pediatric Age Group. Turkish J Pediatr Dis 2022;16:205209.
Correspondence Address / Yazışma Adresi:

Fethi BARLIK

Van Yuzuncu Yil University,

Van Vocational School of Health Services, Van, Türkiye

E-posta: fethi_barlik@hotmail.com
Received / Geliş tarihi : : 12.04.2021 Accepted / Kabul tarihi : 16.06.2021 Online published Elektronik yayın tarihi

DOI: 10.12956/tchd.913972 
Gereç ve Yöntemler: 2013-2015 yılları arasında Van Yüzüncü Yı Üniversitesi Dursun Odabaş Tıp Merkezi Mikrobiyoloji Laboratuvarına gönderilen kan örneklerinde, CMV'nin etken olarak düșünüldüğü 0-14 yaș diliminden çocuk hastaların, CMV-lgM ve CMV-lgG serolojik test sonuçları geriye dönük olarak incelendi. Aynı zamanda CMV-lgM sonucu pozitif bulunan olgularda bunların hematolojik ve biyokimyasal parametrelerle ilişkisi araştırıldı.

Bulgular: 1385 çocuğun CMV-lgM ve IgG testleri yapılmıştır. Bu çocukların \%58'inin erkek ve \%42'sinin kız olduğu belirlendi. CMVIgM bakılan 1363 hastanın 112'si (\%8.2) pozitif olduğu belirlendi. IgM'in yaşa bağlı olarak azalması, istatistik olarak anlamlı bulunmuştur (p<0.01). CMV-lgG bakılan 742 hastanın 707'sinin (\%95.3) pozitif olduğu belirlendi. Benzer şekilde immünoglobulin G seropozitifliğinin yașa paralel olarak artışı, istatistik olarak anlamlı bulunmuștur (p<0.05). CMV-lgM pozitif hastaların, pozitiflik değeri ile bu pozitifli değerinin hematolojik, serolojik ve biyokimyasal parametrelerin her biri ile ayrı ayrı korelasyonu hesaplandı. Korelasyonda anlamlı çıkan değerin 0.49 ile C-reaktive protein olduğu dikkat çekti $(p<0.01)$.

Sonuç: CMV-lgG seroprevalansı gelişmiş ülkelerde yapılan çalışmalarla kıyaslandığında yüksek olarak bulunmuştur. Buna göre, yükselmiş C-reaktive protein düzeylerinin CMV tanısında yarar sağlayacağını düşünmekteyiz.

Anahtar Sözcükler: C-reaktif protein, Cytomegalovirus, Hematolojik parametreler, Pediatrik

\section{INTRODUCTION}

The only source of cytomegalovirus (CMV), which is also known as human herpes virus-5 (HHV-5), is human, and it acts as a pathogen that can infect individuals of all ages, sexes, and races (1). It causes persistent or latent infections by forming nuclear and cytoplasmic inclusions. It is one of the most common causes of congenital viral infection in the world (2). Although infants with congenital CMV appear to be healthy at birth, most of them experience severe neurodevelopmental disorders (3).

The primary CMV infection is mostly seen in children and adolescents, but it is also seen in adults (4). It is reported that $80 \%$ of children may be infected with CMV by the age of three in low-income populations. Although most infections caused by CMV are asymptomatic, children are an important source of transmission for this virus into the home environment. More than $75 \%$ of childhood CMV infections are transmitted perinatally or in the first years of life by salivation, maternal genital secretions, or breast milk after reactivation of the latent maternal virus (5-6). The seroprevalence of CMV has been reported between $40 \%$ and $90 \%$. This change has been reported to peak between the ages of 15 and 49 , including fertility, in parallel with increased sexual activity and early childhood infection. National, population-based seroprevalence studies are essential to reliably assess CMV prevalence and risk factors for infection in order to direct future preventive measures and estimate their cost-effectiveness (7-8).

The aim of this study is to determine the seroprevalence of CMV-immunoglobulin M (CMV-IgM) and CMV-immunoglobulin $G(C M V-\lg G)$ in pediatric patients and to specify its relationship with certain hematological, serological, and biochemical parameters.

\section{MATERIALS and METHOD}

Serological test results of CMV-lgM and CMV-lgG in children aged 0-14 with CMV as a causative agent were analyzed retrospectively in the blood samples sent to the Microbiology Laboratory of Dursun Odabas Medical Center of Van Yuzuncu
Yil University between 2013 and 2015. CMV-lgM-positive cases were investigated for their relationship with hematological parameters (complete blood count, CBC; Hemoglobin, Hb; white blood cells, WBC; lymphocytes, LY; neutropenia; eosinophilia; thrombocytopenia presence; prothrombin time, $\mathrm{PT}$; partial thromboplastin time, PTT; erythrocyte sedimentation rate, ESR) and biochemical parameters (aspartate aminotransferase, AST; alanine aminotransferase, ALT; lactate dehydrogenase, $\mathrm{LDH}$; and C-reactive protein, CRP).

Blood samples were centrifuged at $10.000 \mathrm{rpm}$ for 15 minutes. Serums were tested for CMV-IgM and CMV-IgG using a Cobas E601 (Roche Diagnostics, Germany) analyzer. CBC was analyzed with a Beckman Coulter LH780 (ABD) device and PT and PTT with an STA compact (Stago, France) device in CMVIgM positive patients. AST, ALT, and LDH were analyzed with an Architecht C8000 (Abbott Diagnostics, ABD) device, and CRP was analyzed with an NFL BN-II (Siemens, Germany) device.

CMV-IgM (COI) was evaluated as follows: $\geq 1$ was considered positive, between 0.7 and 1 was considered to be undetermined, and $<0.7$ was considered to be negative. CMV-lgG $(\mathrm{IU} / \mathrm{ml})$ was evaluated as follows: $\geq 1$ was considered positive, between 0.5 and 1 was considered to be undetermined, and $<0.5$ was considered to be negative. Anemia was defined as a hemoglobin level $<11 \mathrm{~g} / \mathrm{dL}$, thrombocytopenia was defined as a platelet count $<150,000 / \mathrm{mm}^{3}$, and leukocytosis was defined as a leukocyte count $>11,000 / \mathrm{mm}^{3}$. Leukocyte counts $<4,000 / \mathrm{mm}^{3}$ were considered leukopenia, neutrophil counts $<1,500 / \mathrm{mm}^{3}$ were considered neutropenia, and eosinophil counts $>0.5 / \mathrm{mm}^{3}$ were considered eosinophilia. Elevated mean platelet volume was defined as $>10.4 \mathrm{fL}$. Levels of PT $>15 \mathrm{~s}$, PTT $>40 \mathrm{~s}$, ESR $>20 \mathrm{~mm} / \mathrm{h}, \mathrm{CRP}>5 \mathrm{mg} / \mathrm{dL}$, AST $>40 \mathrm{U} / \mathrm{L}, \mathrm{ALT}>40 \mathrm{U} / \mathrm{L}$, and $\mathrm{LDH}>500 \mathrm{U} / \mathrm{L}$ were accepted as elevated levels.

This study was conducted in accordance with the Helsinki Declaration Principles. Ethics committee approval for our study was obtained from our university's committee (date: 10.03.2015, number: 08).

\section{Statistical Analysis}

Continuous variables, the mean and standard deviation, are expressed as minimum and maximum values, while categorical 
variables are expressed as numbers and percentages. In terms of continuous variables, one-way analysis of variance was used in comparisons based on categorical variables. Pearson's correlation coefficient was used to determine the relationships between continuous variables, while the Chi-square test was used to determine the relationships between categorical variables. The $Z$ test was used to compare the difference between the ratios. The statistical significance level was taken as $5 \%$ in the calculations, and SPSS Ver. 21.0 was used for these calculations.

\section{RESULTS}

\section{Demographic Information}

A total of 1.385 children aged $0-14$ years old were tested for CMV-IgM and CMV-lgG between 2015 and 2017; 1.363 of these children were tested for CMV-IgM, 742 were tested for CMV-lgG, and 740 were tested for both CMV-lgM and CMV$\operatorname{lgG}$. Eight hundred and three of the 1.385 children were male (58\%), and 582 were female (42\%).

\section{The Results of CMV-IgM}

Out of the 1.363 patients who were tested for CMV-IgM, 790 (58\%) were male, and 573 (42\%) were female; 146 of 1.363 patients were found to be positive or undetermined. One hundred and twelve (8.2\%) patients were found to be positive for CMV-IgM when the undetermined tests were excluded. The rate of positivity was found to be $8.2 \%$ in male and female patients (male: 65/790, female: 47/573).

A statistically significant relationship was found between IgM seropositivity and age $(p<0.01)$. The rate of $\operatorname{lgM}$ in a oneyear increase in the age of the children studied decreases by $0.69 \%$. In this case, when estimating IgM seropositivity using patient age, the accuracy reaches $71.3 \%$ (r: $71.3, p<0.01)$. In other words, $71.3 \%$ of the variation in IgM seropositivity can be explained by variation in age. Figure 1 shows the CMV-IgM positivity of the patients according to age and gender.

The relationships between the hematological and other biochemical parameters of the 112 patients found to be CMV-

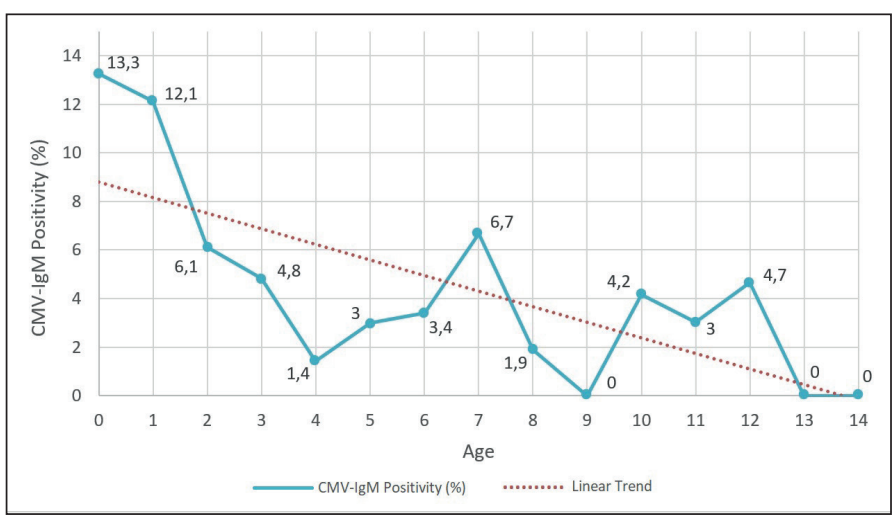

Figure 1: The Relationship between CMV-lgM positivity and age.



Figure 2: The Relationship between CMV-lgG positivity and age.

IgM positive are summarized in Table I. The cut-off level of CMVIgM-positive patients and the correlation of the hematological, serological, and biochemical parameters with this positivity were calculated for each parameters separately. The value that was considered to be meaningful in correlation was found to be CRP at a rate of $49.1 \%(p<0.01)$ (Table I).

\section{The Results of CMV-IgG}

Of the 742 patients who were tested for CMV-IgG, 420 (57\%) were male, and 322 (43\%) were female; 717 of the 742 patients were tested positive and considered to be undetermined. Excluding the undetermined, 707 (95.3\%) patients were found to be positive for CMV-lgG. The rate of positivity was found to be $95 \%$ in male and $95.7 \%$ female patients (male: 399/420, female: 308/322).

Similarly, a statistically significant relationship was found between IgG seropositivity and age $(p<0.01)$. The rate of IgG in a one-year increase in the age of the children studied increases by $0.567 \%$. In this case, when estimating IgG seropositivity by using patient age, the accuracy reaches $48.6 \%$. Positive values in the neonatal period may be due to IgG antibodies from the mother. The difference is statistically significant when CMVIgG values in patients between 1 and 5 years and between 5 and 14 years old, excluding the 0-years-old age group, are compared $(p<0.001)$. Figure 2 shows the CMV-IgG-positive patients according to age.

\section{DISCUSSION}

Primary CMV infections occur mostly in adolescence or early childhood and are usually asymptomatic in healthy children and adults. Symptomatic CMV infections are generally manifested as a non-specific febrile disease or as a mild, selflimiting mononucleosis syndrome. However, there are many reports of severe or prolonged symptomatic CMV infections in immunosuppressive patients (9). Anti-CMV IgM-type antibodies indicate primary or recurrent infections, while lgGtype antibodies indicate previous infections. IgM antibodies can 
Table I: Laboratory findings of CMV-IgM.

\begin{tabular}{|c|c|c|c|c|c|}
\hline Laboratory test & n (\%) & Range & Mean \pm SD & $\begin{array}{c}\text { No. } \\
\text { Patients } \\
\text { tested }\end{array}$ & Correlation \\
\hline $\begin{array}{l}\text { Hematologic parameters } \\
\text { Leukopenia }\left(10^{3} / \mathrm{mL}\right) \\
\text { Leucocytosis }\left(10^{3} / \mathrm{mL}\right) \\
\text { Neutropenia }\left(10^{3} / \mathrm{mL}\right) \\
\text { Eosinophilia }\left(10^{3} / \mathrm{mL}\right) \\
\text { Anemia }(\mathrm{Hb}: \mathrm{g} / \mathrm{dL})^{*} \\
\text { Anemia }(\mathrm{Hb}: \mathrm{g} / \mathrm{dL})^{\dagger} \\
\text { Thrombocytopenia }\left(10^{3} / \mathrm{mL}\right) \\
\text { Pancytopenia } \\
\text { Elevated PT } \\
\text { Elevated PTT }\end{array}$ & $\begin{array}{c}3(2.7) \\
61(54.5) \\
12(10.7) \\
11(9.8) \\
29(53.7) \\
27(49.1) \\
26(23.2) \\
1(0.9) \\
22(19.6) \\
7(6.3)\end{array}$ & $\begin{array}{l}2.3-99.9 \\
2.3-99.9 \\
0.3-32.7 \\
0.0-1.9 \\
5.6-15.9 \\
6.1-14.0 \\
0.2-786.0 \\
\\
11.8-110.0 \\
20.5-73.6\end{array}$ & $\begin{array}{c}14.0-11.7 \\
14.0-11.7 \\
4.0-4.3 \\
0.3-0.3 \\
10.9-2.0 \\
10.9-2.0 \\
301.1-192.3 \\
16.9-12.4 \\
32.3-7.9\end{array}$ & $\begin{array}{r}109 \\
109 \\
76 \\
76 \\
54 \\
55 \\
109 \\
109 \\
68 \\
68\end{array}$ & $\begin{array}{l}0.036 \\
0.036 \\
0.121 \\
-0.104 \\
-0.072 \\
-0.072 \\
-0.068 \\
0.008 \\
0.051\end{array}$ \\
\hline $\begin{array}{l}\text { Other parameters } \\
\text { Elevated ESR }(\mathrm{mm} / \mathrm{h}) \\
\text { Elevated CRP }(\mathrm{mg} / \mathrm{L}) \\
\text { Elevated LDH }(\mathrm{U} / \mathrm{L}) \\
\text { Elevated AST }(\mathrm{U} / \mathrm{L}) \\
\text { Elevated ALT }(\mathrm{U} / \mathrm{L})\end{array}$ & $\begin{array}{l}15(13.4) \\
35(31.3) \\
44(39.3) \\
83(74.1) \\
62(55.4)\end{array}$ & $\begin{array}{c}3.0-57.0 \\
3.2-268.0 \\
4.2-2765.0 \\
17.0-1466.0 \\
7.0-461.0\end{array}$ & $\begin{array}{c}19.1-12.3 \\
18.9-41.6 \\
600.9-422.3 \\
119.1-164.1 \\
94.8-96.8\end{array}$ & $\begin{array}{c}41 \\
86 \\
90 \\
110 \\
111\end{array}$ & $\begin{array}{l}-0.068 \\
0.491^{\ddagger} \\
-0.042 \\
-0.012 \\
-0.013\end{array}$ \\
\hline
\end{tabular}

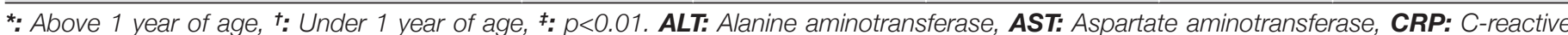
protein, ESR: Erythrocyte sedimentation rate, $\boldsymbol{H b}$ : Hemoglobin, LDH: Lactate dehydrogenase, PT: Prothrombin time; PTT: Partial thromboplastin time.

remain positive for a long time as well as become negative after the formation of IgG antibodies. CMV-IgM positivity does not indicate primary infection. CMV-IgM positivity can occur as a false positivity because of reactivation as well as acute infection (10).

Several studies have been performed on CMV seropositivity in Turkey. Ataman et al. (11) reported that CMV-lgG seropositivity increases with age, and the rates in age groups 1-6, 7-14, and 15-49 were $82.1 \%, 92 \%$, and $97.8 \%$, respectively. Köksaldı et al. (12) reported that CMV-lgG positivity was found at a rate of $96.2 \%$ in 0-14-year-old children admitted to Hatay Women and Children Hospital. Okur et al. (13) reported that the CMV$\lg G$ and $C M V-I g M$ seropositivity in patients between 0 and 18 years old in the Van Lake Region was 93.1\% and 9.1\%, respectively. In a comprehensive study of Germany by Voigt et al. (6), it was reported that between 2003 and 2006, the CMVIgG seropositivity of patients aged 1-7 was $93 \%$. In the same study, it was noted that CMV seroprevalence increased with low socioeconomic status (CMV seroprevalence was $72 \%$ in low-income populations, $61 \%$ in middle-income populations, and 55\% in high-income populations). Between 2011 and 2012, a national health and nutritional examination survey reported $20.7 \%$ seroprevalence of CMV-lgG among children between 1 and 5 years of age in the United States. It was also reported that the lowest seroprevalence was in the 1-year-old age group at $12.3 \%$ and that the highest seroprevalence was in the 5-year-old age group at $31.1 \%$ (14). Compared with these studies, the rates of CMV-lgG seroprevalence in our study were $89 \%$ for the 1 -5-year-old age group and $97 \%$ for the 5 - 14 -yearold age group. The determination of seropositivity at such high rates shows that Van province is in a high-risk group in terms of CMV infection. Compared with other cities in Turkey, Van province, where this research was conducted, has a low level of social and economic development (15). It is estimated that the high CMV-lgG seroprevalence in this province is associated with this situation.

Disease settings such as infections, tissue damage, and immunological processes initiate a systematic response in the organism in a certain process. These disease settings induce the acute phase response, and the substances formed as a result of the response are called acute phase reactants. CRP is an acute phase reactant produced by the liver, especially under the control of cytokines with interleukin-6 (16). Studies have shown that there is a relationship between CMV antibodies and high CRP levels. Zhu et al. (17) suggest that CMV infection triggers an inflammatory response reflecting high levels of CRP and partially paves the way for coronary artery disease through CMV-induced inflammation. It is also argued that CMV seropositivity is significantly correlated with high CRP levels, which might stimulate a subclinical inflammatory response. Nubling et al. (18) reported slightly elevated CRP levels during active CMV infection in immunosuppressive patients. Costalonga et al. (19) reported a relationship between the severity of clinical findings in patients with active CMV infections and elevated serum CRP levels. Similarly, de Matos et al. (20) reported that CMP seroprevalence in Bahia, Brazil, shows a statistically significant relationship between CRP levels in serum samples and CMV. In our study, the correlation between CMV level and CRP was also found to be statistically significant.

Jia et al. (21) reported that CMV DNA levels had a significant association with ESR and CRP levels, so CMV infections could play a role in the inflammatory response in ESR. In congenital 
CMV infections, except for febrile diseases and hepatitis, the increase in liver enzymes in CMV-IgM positivity has been emphasized by some studies (22). In our study, the elevation of ESR, LDH, AST, and ALT was found to be $13 \%, 39 \%, 74 \%$, and $55 \%$, respectively. This positivity did not correlate with CMV-IgM increases. In infectious diseases, either as a result of a direct effect on the bone marrow or immune response to the disease, different hematological findings may occur (23). In our study, the rate of patients with leukocytosis, anemia, and thrombocytopenia was found to be $55 \%, 50 \%$, and $23 \%$, respectively. There was not a significant correlation.

In conclusion, the seroprevalence of CMV-lgG found in our study was high compared to what has been found in developed countries. Similar to other studies conducted previously, it has been found that CMV-IgM seroprevalence decreases depending on age and CMV-lgG seroprevalence increases depending on age. The results of the study indicate that the increase of CRP in CMV-IgM-positive patients is statistically significant.

\section{REFERENCES}

1. Bekdaş M. Hastanede izlenen sitomegalovirus enfeksiyonlu olguların değerlendirilmesi. Bakırköy Tıp Derg 2013; 9: 39-41.

2. Buller RS, Storch GA, Arens MQ. Human cytomegalovirus. Washington, DC: ASM Press; 2003.

3. Çetinkol Y, Çalgın MK, Yııdırım AA. Ordu ilinde hamilelik döneminde Önemli viral patojenlerin araştıııması. ODÜ Tıp Derg 2016; 3: 64-7.

4. Lopo S, Vinagre E, Palminha P, Paixão MT, Nogueira P, Freitas MG. Seroprevalence to cytomegalovirus in the Portuguese population, 2002-2003. Euro SurveilL 2011; 16:19896.

5. Noyola DE, Valdez-López BH, Hernández-Salinas AE, Santos-Díaz MA, Noyola-Frías MA, Reyes-Macías JF, et al. Cytomegalovirus excretion in children attending day-care centers. Arch Med Res 2005; 36: 590-93.

6. Voigt S, Schaffrath Rosario A, Mankertz A. Cytomegalovirus seroprevalence among children and adolescents in Germany: Data from the german health interview and examination survey for children and adolescents (KiGGS), 2003-2006. Open Forum Infect Dis 2015;3:193-200.

7. Anuma ON, Umeora OUJ. Seroprevalence of cytomegalovirus antibodies among antenatal clinic attendees in Abakaliki, Nigeria. Afr J Med Health Sci 2016;15: 24-9.

8. Korndewal MJ, Mollema L, Tcherniaeva I, van der Klis F, Kroes AC, Oudesluys-Murphy AM, et al. Cytomegalovirus infection in the Netherlands: seroprevalence, risk factors, and implications. J Clin Virol 2015;63:53-8.

9. Vilibic-Cavlek T, Kolaric B, Beader N, Vrtar I, Tabain I, MlinaricGalinovic G. Seroepidemiology of cytomegalovirus infections in Croatia. Wien Klin Wochenschr 2017; 129:129-35.

10. Karakoç ZÇ, Taşçıoğlu D, Tekin S, Şimşek B. Sağlıklı erişkinde akut sitomegalovirus hastalığı: dört olgu sunumu. Klimik Dergisi 2016; 29: 39-42.

11. Ataman S, Colak D, Günseren F, Senol Y, Colak T, Aktekin MR, et al. Antalya'da sitomegalovirus seroepidemiyolojisinin toplum kaynaklı kesitsel bir çalışma ile araştırıması ve türkiye verilerinin derlenmesi. Mikrobiyol Bül 2007; 41: 545-55.
12. Koksaldi-Motor V, Evirgen O, Azaroglu I, Inci M, Ozer B, Arica S. Prevalence of toxoplasmosis, cytomegalovirus and rubella lgG antibodies in Hatay women and children. West Indian Med J 2012; 61: 154-7.

13. Okur M, Erbey F, Kaya A, Güven A. Van Gölü havzasında 0-18 yaş grubu çocuklarda sitomegalovirus, rubella ve toksoplazma seroprevalansı. Konuralp Tıp Derg 2012; 4:13-6.

14. Lanzieri TM, Kruszon-Moran D, Amin MM, Bialek SR, Cannon MJ, Carroll MD, et al. Seroprevalence of cytomegalovirus among children 1 to 5 years of age in the United States from the national health and nutrition examination survey of 2011 to 2012. Clin Vaccine Immunol 2015; 22: 245-47.

15. Temurlenk M, Abar H. Türkiye'deki Illerin Sosyoekonomik Gelişmişlik Seviyeleri: 2008-2016 Dönemi. Atatürk Üni IïB Derg 2019; 33: 1115-35.

16. Yücel D. C-reactive protein vs. High-sensitivity c-reactive protein: what is the difference?. Türk Biyokimya Derg 2014; 39: 43-4.

17. Zhu J, Quyyumi AA, Norman JE, Csako G, Epstein SE. Cytomegalovirus in the pathogenesis of atherosclerosis: the role of inflammation as reflected by elevated c-reactive protein levels. J Am Coll Cardiol 1999;34: 1738-43.

18. Nubling GJ, Korn S, Ludwig B, Stephan C, Doer HW, Peiser W. Primary cytomegalovirus infection in an outpatient settinglaboratory markers and clinical aspects. Infection 2003; 31: 31823.

19. Costalonga EC, Melo NCV, Rodrigues CE, Sette LHBC, lanhez LE. The potential role of $\mathrm{c}$-reactive protein in distinguishing cytomegalovirus from tuberculosis and bacterial infections in renaltransplant recipients. Clin Transplant 2009;23: 710-15.

20. de Matos SB, Meyer R, Lima FWDM. Seroprevalence and serum profile of cytomegalovirus infection among patients with hematologic disorders in Bahia state, Brazil. Rev Med Virol 2011; 83: 298-304.

21. Jia J, Shi H, Liu M, Liu T, Gu J, Wan L, et al. Cytomegalovirus infection may trigger adult-onset still's disease onset or relapses. Front Immunol 2019;10:898.

22. Just-Nübling G, Korn S, Ludwig B, Stephan C, Doerr HW, Preiser W. Primary cytomegalovirus infection in an outpatient settinglaboratory markers and clinical aspects. Infection 2003;31:318-23.

23. Tokgöz H, Çalışkan Ü. Çocuklarda enfeksiyon hastalıklarında görülen hematolojik bulgular. Selcuk Med J 2017;33: 63-6. 